\title{
Targeting the Peripheral Inflammatory Response to Stroke: Role of the Spleen
}

\author{
Keith R. Pennypacker
}

Received: 12 September 2014 / Accepted: 15 September 2014 / Published online: 26 September 2014

(C) Springer Science+Business Media New York 2014

The migration of immune cells into the stroke-damaged brain has been reported for decades $[1,2]$ but its relationship to neurodegeneration is still not completely understood. Cells of the innate immune system are among the first immune cells to extravasate along with the adaptive immune cells infiltrating at later time points [3]. The inflammatory response elicited from these immune cells directly exacerbates the neurodegeneration in the ischemic area as well as indirectly by activating microglia [4]. This observation has led to the use of antiinflammatory therapies in stroke treatment. One problem with this approach is the potentiation of the post-stroke immune suppression, which leads to increased infection rates [5]. The clinical trial evaluating anti-ICAM-1 therapy is an example of this issue in which one of the adverse events was increased incidence of pneumonia in the treatment group [6]. Thus, therapies that are more selective or targeted at the neurodegenerative response by the immune system could be administered to inhibit further damage with minimal contribution to the post-stroke immune suppression.

The spleen has been reported to decrease in size as a response to stroke in rodents $[7,8]$. This reduction in tissue mass is caused at least in part to the activation of the sympathetic nervous system to induce contraction of the splenic capsule [9]. An initial study examining the spleen size of stroke patients suggests that spleen reduces in size after stroke in humans [10]. Removal of the spleen significantly reduces infarct volume in the rodent brain after experimental stroke [11-13]. Splenectomy has also proven to be beneficial in other types of brain injuries, such as hemorrhagic stroke and traumatic brain injury [14-17]. In fact, the splenic response to ischemic injury is a universal physiological one. Reports concerning a number of organ systems indicate that the

K. R. Pennypacker $(\bowtie)$

University of South Florida, Tampa, FL, USA

e-mail:kpennypa@health.usf.edu removal of a spleen protects the liver [18], intestine [19], kidney [20], and heart [21] from ischemic injury. Understanding the splenic response to ischemic injury would not only benefit stroke but potentially other ischemic injuries to all other tissues and organ systems.

The splenic humoral response to stroke comprises of a plethora of inflammatory cytokines and chemokines. Messenger RNAs (mRNAs) for IL-1 $\beta[22,14]$, TNF $\alpha[14$, $22,23], \mathrm{IFN} \gamma$ [23], and IL-6 [23, 14] have all been reported as upregulated in the spleen following ischemic or hemorrhagic stroke. The mRNAs for chemokines such as CXCL2 and CXCL10 have been found to be elevated following middle cerebral artery occlusion (MCAO) in mice [24, 23]. Increased splenic levels of IFN $\gamma$ protein following MCAO has been found in rats [25].

Most interesting, the administration of IFN $\gamma$ reverses the protective effects of splenectomy, [25] suggesting this inflammatory cytokine is mediating the neurodegenerative effects. Blockade of IFN $\gamma$ signaling, such as the use of IFN $\gamma^{-/-}$mice [26] or inhibiting IFN $\gamma$ with a neutralizing antibody injected directly into the brain reduced stroke-induced neurodegeneration [27]. Using antibodies that preclude the IFN $\gamma$-producing cells from entering the injured brain also leads to reduced infarct volume [28]. Systemic administration of an IFN $\gamma$ neutralizing antibody significantly decreases infarct volume [29] adding further evidence for the negative role of this inflammatory cytokine in stroke. Stroke patients who developed a $\mathrm{Th}_{1}$ response to brain antigens at 90 days post-stroke were more likely to have a poorer outcome regardless of age or baseline stroke severity [30, 31]. IFN $\gamma$ is considered a signature cytokine of a $\mathrm{Th}_{1}$ response, which could implicate IFN $\gamma$ as being detrimental following stroke in patients when an inflammatory $\mathrm{T}$ cell response is generated against brain antigens.

Since IFN $\gamma$ is not directly neurotoxic [32], its downstream activation of macrophages/microglia appears to be the 
mechanism by which this inflammatory cytokine can indirectly be responsible for delayed neurodegeneration in stroke. Downstream signaling of IFN $\gamma$ induces the expression of the chemokine interferon-inducible protein 10 (IP-10), also known as CXCL10. This cytokine is pro-inflammatory and drives the $\mathrm{Th}_{1}$ response by interacting with the CXCR3 receptor [33]. Microglia/macrophages produce IP-10 after IFN $\gamma$ stimulation [29], which results in the chemotaxis of $\mathrm{Th}_{1}$ cells to the site of injury. IP-10 prevents the activation of $\mathrm{Th}_{2}$ cells by competitive antagonism of the CCR3 receptor [33] to further promote the inflammatory state. Thus, an IFN $\gamma$ induced feed forward inflammatory cycle is initiated when IP-10 secreted from macrophage/microglia recruits T cells to the infarct. The T cells express and secrete more IFN $\gamma$, leading to further expression of IP-10 in macrophages/microglia and additional neurodegeneration.

One recent study used recombinant TCR ligand (RTL) that consists of the specific domains of the MHC II molecule, which blocks $\mathrm{T}$ cells from becoming inflammatory and concomitantly deactivates the splenic response. Mice treated with RTL at $4 \mathrm{~h}$ after stroke resulted in decreased infarct volume and inflammatory response from the spleen [34]. This study incorporated elderly mice, and this treatment was equally effective despite age of the mice. Most interestingly, the RTL differentially affected components of the immune response in the elderly and young mice but still resulted in a blunted immune response reducing neurodegeneration.

Other potential targets have been reported that could attenuate the inflammatory response to neurological insult. The chemokine, CCL20, originates from the spleen after brain injury and has direct cytotoxic effects on neurons and oligodendrocytes [35]. Researchers are examining the action of signaling through cannabinoid and serotonin receptors [36] and the use of known anti-inflammatory compounds to alter the immune response to stroke [37]. Another interesting strategy is to activate the immune system's anti-inflammatory response to counter the inflammatory one [38]. Studies such as these are slowly unraveling the role of the immune system in responding to brain injury but will shed insight into chronic neurological disorders as well [39].

Ideally, pharmacological intervention that blunts the splenic response to stroke will arrest further neurodegeneration without worsening post-immune suppression. However, such a treatment would probably not enhance cellular survival/ repair processes necessary for functional recovery. An optimal therapy would require a combination treatment that prevents further damage while promoting neural cell survival and stimulating repair of the initial damage leading to functional recovery of the brain area adversely affected by stroke. Cellular therapies contain both of these properties and have shown promise in stroke and other rodent models of neurological insult [40-42]. Much work is needed to translate these exciting findings into creating a treatment for stroke in the clinical setting.

Conflict of Interest None

\section{References}

1. Schroeter M, Jander S, Witte OW, Stoll G. Local immune responses in the rat cerebral cortex after middle cerebral artery occlusion. $\mathrm{J}$ Neuroimmunol. 1994;55(2):195-203.

2. Jander S, Kraemer M, Schroeter M, Witte OW, Stoll G. Lymphocytic infiltration and expression of intercellular adhesion molecule-1 in photochemically induced ischemia of the rat cortex. J Cereb Blood Flow Metab. 1995;15(1):42-51.

3. Stevens SL, Bao J, Hollis J, Lessov NS, Clark WM, Stenzel-Poore MP. The use of flow cytometry to evaluate temporal changes in inflammatory cells following focal cerebral ischemia in mice. Brain Res. 2002;932(1-2):110-9.

4. Tang XN, Zheng Z, Yenari MA. Bone marrow chimeras in the study of experimental stroke. Transl Stroke Res. 2012;3(3):341-7. doi:10. 1007/s12975-012-0169-6.

5. Prass K, Meisel C, Hoflich C, Braun J, Halle E, Wolf T, et al. Strokeinduced immunodeficiency promotes spontaneous bacterial infections and is mediated by sympathetic activation reversal by poststroke T helper cell type 1-like immunostimulation. J Exp Med. 2003;198(5):725-36.

6. Use of anti-ICAM-1 therapy in ischemic stroke: results of the Enlimomab acute stroke trial. Neurology. 2001;57(8):1428-34.

7. Vendrame M, Gemma C, Pennypacker KR, Bickford PC, Davis Sanberg C, Sanberg PR, et al. Cord blood rescues stroke-induced changes in splenocyte phenotype and function. Exp Neurol. 2006;199(1):191-200.

8. Offner H, Subramanian S, Parker SM, Wang C, Afentoulis ME, Lewis A, et al. Splenic atrophy in experimental stroke is accompanied by increased regulatory $\mathrm{T}$ cells and circulating macrophages. J Immunol. 2006;176(11):6523-31.

9. Ajmo CT, Jr., Collier LA, Leonardo CC, Hall AA, Green SM, Womble TA et al. Blockade of adrenoreceptors inhibits the splenic response to stroke. Exp Neurol. 2009.

10. Sahota P, Vahidy F, Nguyen C, Bui TT, Yang B, Parsha K, et al. Changes in spleen size in patients with acute ischemic stroke: a pilot observational study. Int J Stroke. 2013;8(2):60-7.

11. Ajmo Jr CT, Vernon DO, Collier L, Hall AA, Garbuzova-Davis S, Willing A, et al. The spleen contributes to stroke-induced neurodegeneration. J Neurosci Res. 2008;86:2227-34. doi:10.1002/jnr.21661.

12. Jin R, Zhu X, Liu L, Nanda A, Granger DN, Li G. Simvastatin attenuates stroke-induced splenic atrophy and lung susceptibility to spontaneous bacterial infection in mice. Stroke. 2013;44(4):1135-43. doi:10.1161/STROKEAHA.111.000633.

13. Ostrowski R, Schulte R, Nie Y, Ling T, Lee T, Manaenko A, et al. Acute splenic irradiation reduces brain injury in the rat focal ischemic stroke model. Transl Stroke Res. 2012;3:473-81. doi:10.1007/ s12975-012-0206-5.

14. Lee ST, Chu K, Jung KH, Kim SJ, Kim DH, Kang KM, et al. Antiinflammatory mechanism of intravascular neural stem cell transplantation in haemorrhagic stroke. Brain. 2008;131(Pt 3):616-29.

15. Li M, Li F, Luo C, Shan Y, Zhang L, Qian Z, et al. Immediate splenectomy decreases mortality and improves cognitive function of rats after severe traumatic brain injury. J Trauma. 2011;71(1):141-7.

16. Das M, Leonardo CC, Rangooni S, Mohapatra SS, Mohapatra S, Pennypacker KR. Lateral fluid percussion injury of the brain induces CCL20 inflammatory chemokine expression in rats. J Neuroinflammation. 2011;8:148. 
17. Walker PA, Shah SK, Jimenez F, Gerber MH, Xue H, Cutrone $\mathrm{R}$, et al. Intravenous multipotent adult progenitor cell therapy for traumatic brain injury: preserving the blood brain barrier via an interaction with splenocytes. Exp Neurol. 2010;225(2): $341-52$.

18. Okuaki Y, Miyazaki H, Zeniya M, Ishikawa T, Ohkawa Y, Tsuno S, et al. Splenectomy-reduced hepatic injury induced by ischemia/ reperfusion in the rat. Liver. 1996;16(3):188-94.

19. Savas MC, Ozguner M, Ozguner IF, Delibas N. Splenectomy attenuates intestinal ischemia-reperfusion-induced acute lung injury. $\mathrm{J}$ Pediatr Surg. 2003;38(10):1465-70.

20. Jiang H, Meng F, Li W, Tong L, Qiao H, Sun X. Splenectomy ameliorates acute multiple organ damage induced by liver warm ischemia reperfusion in rats. Surgery. 2007;141(1):32-40.

21. Leuschner F, Panizzi P, Chico-Calero I, Lee WW, Ueno T, Cortez-Retamozo V, et al. Angiotensin-converting enzyme inhibition prevents the release of monocytes from their splenic reservoir in mice with myocardial infarction. Circ Res. 2010;107(11):1364-73.

22. Schwarting S, Litwak S, Hao W, Bahr M, Weise J, Neumann H. Hematopoietic stem cells reduce postischemic inflammation and ameliorate ischemic brain injury. Stroke. 2008;39(10):2867-75.

23. Hurn PD, Subramanian S, Parker SM, Afentoulis ME, Kaler LJ, Vandenbark AA, et al. T- and B-cell-deficient mice with experimental stroke have reduced lesion size and inflammation. J Cereb Blood Flow Metab. 2007;27(11):1798-805.

24. Offner H, Subramanian S, Parker SM, Afentoulis ME, Vandenbark AA, Hurn PD. Experimental stroke induces massive, rapid activation of the peripheral immune system. J Cereb Blood Flow Metab. 2006;26(5):654-65.

25. Seifert HA, Leonardo CC, Hall AA, Rowe DD, Collier LA, Benkovic $\mathrm{SA}$, et al. The spleen contributes to stroke induced neurodegeneration through interferon gamma signaling. Metab Brain Dis. 2012;27(2): 131-41. doi:10.1007/s11011-012-9283-0.

26. Yilmaz G, Arumugam TV, Stokes KY, Granger DN. Role of T lymphocytes and interferon-gamma in ischemic stroke. Circulation. 2006;113(17):2105-12.

27. Liesz A, Suri-Payer E, Veltkamp C, Doerr H, Sommer C, Rivest S, et al. Regulatory $\mathrm{T}$ cells are key cerebroprotective immunomodulators in acute experimental stroke. Nat Med. 2009;15(2):192-9. doi: 10.1038/nm.1927.

28. Liesz A, Zhou W, Mracsko E, Karcher S, Bauer H, Schwarting S, et al. Inhibition of lymphocyte trafficking shields the brain against deleterious neuroinflammation after stroke. Brain. 2011;134(Pt 3): 704-20. doi:10.1093/brain/awr008.

29. Seifert HA, Collier LA, Chapman CB, Benkovic SA, Willing AE, Pennypacker KR. Pro-inflammatory interfon gamma signaling is directly associated with stroke induced neurodegeneration. J Neuroimmune Pharmacology. 2014. doi:10.1007/s11481-014-9560-2.
30. Becker KJ, Kalil AJ, Tanzi P, Zierath DK, Savos AV, Gee JM et al. Autoimmune responses to the brain after stroke are associated with worse outcome. Stroke. 2011.

31. Becker K. Autoimmune responses to brain following stroke. Transl Stroke Res. 2012;3(3):310-7. doi:10.1007/s12975-012-0154-0.

32. Seifert HA, Hall AA, Chapman CB, Collier LA, Willing AE, Pennypacker KR. A transient decrease in spleen size following stroke corresponds to splenocyte release into systemic circulation. J Neuroimmune Pharmacol. 2012;7(4):1017-24. doi:10.1007/ s11481-012-9406-8.

33. Loetscher P, Pellegrino A, Gong JH, Mattioli I, Loetscher M, Bardi $\mathrm{G}$, et al. The ligands of CXC chemokine receptor 3, I-TAC, Mig, and IP10, are natural antagonists for CCR3. J Biol Chem. 2001;276(5): 2986-91.

34. Offner H, Dotson AL, Zhu W, Libal N, Alkayed NJ. Different immunological mechanisms govern protection from experimental stroke in young and older mice with recombinant TCR ligand therapy. Front Cell Neurosci. 2014:(in press). doi: 10.3389/fncel.2014. 00284.

35. Leonardo CC, Musso J, Das M, Rowe DD, Collier LA, Mohapatra S, et al. CCL20 is associated with neurodegeneration following experimental traumatic brain injury and promotes cellular toxicity in vitro. Transl Stroke Res. 2012;3(3):357-63.

36. Zhang M, Mahadevan A, Amere M, Li H, Ganea D, Tuma RF. Unique effects of compounds active at both cannabinoid and serotonin receptors during stroke. Transl Stroke Res. 2012;3(3):348-56. doi:10.1007/s12975-012-0197-2.

37. Switzer JA, Sikora A, Ergul A, Waller JL, Hess DC, Fagan SC. Minocycline prevents IL-6 increase after acute ischemic stroke. Transl Stroke Res. 2012;3(3):363-8. doi:10.1007/s12975-0120150-4.

38. Offner H, Hurn PD. A novel hypothesis: regulatory B lymphocytes shape outcome from experimental stroke. Translational stroke research. 2012;3(3). doi: 10.1007/s12975-012-0187-4.

39. Rodrigues MC, Voltarelli JC, Sanberg PR, Borlongan CV, Garbuzova-Davis S. Immunological aspects in amyotrophic lateral sclerosis. Transl Stroke Res. 2012;3(3):331-40. doi:10.1007/ s12975-012-0177-6.

40. Golden JE, Shahaduzzaman M, Wabnitz A, Green S, Womble TA, Sanberg PR, et al. Human umbilical cord blood cells alter blood and spleen cell populations after stroke. Transl Stroke Res. 2012;3(4): 491-9. doi:10.1007/s12975-012-0208-3.

41. Chen J, Li Y, Katakowski M, Chen X, Wang L, Lu D, et al. Intravenous bone marrow stromal cell therapy reduces apoptosis and promotes endogenous cell proliferation after stroke in female rat. J Neurosci Res. 2003;73(6):778-86. doi:10.1002/jnr.10691.

42. Hetz RA, Bedi SS, Olson S, Olsen A, Cox Jr CS. Progenitor cells: therapeutic targets after traumatic brain injury. Transl Stroke Res. 2012;3(3):318-23. doi:10.1007/s12975-012-0192-7. 